Vartmann György

\title{
A Magyar Honvédség belső altisztképzési rendszerének elemzése (2017. szeptember - 2019. július)
}

\section{Analysis of the Internal Non-Commissioned Officer Training System of the Hungarian Defence Forces (September 2017 - July 2019)}

\begin{abstract}
Absztrakt
A cikk a Magyar Honvédség belső altisztképzési rendszerét mutatja be 2017. szeptembertöl 2019. júliusig. Félévenkénti bontásban mutatja be az MH Altiszti Akadémián folyó képzések kibocsátási adatait. Elemző módon összesíti a képzési adatokat. Végezetül az elemzés alapján javaslatokat fogalmaz meg.

Kulcsszavak: katonai oktatás, belső altisztképzés, altisztképzés, MH AA, katonai képzési adatok
\end{abstract}

\section{Abstract}

The article shows the Non-Commissioned Officer Internal Training System of the Hungarian Defence Forces from September 2017 to July 2019. It presents the semester output data of the HDF NCOA training courses. It aggregates training data in an analytical way. Finally, based on the analysis, it makes recommendations.

Keywords: military education, internal NCO education, NCO education, HDF NCOA, military education data 


\section{Bevezetés}

A Magyar Honvédség Altiszti Akadémia mint katonai szakképzésre és katonai kiképzésre kijelölt szervezet (MH AA) a 2012. május 30-án kelt 772-13/2012. nyilvántartási számú alapító okirata értelmében, ${ }^{2} 2012$. augusztus 1-jétől kezdte meg a müködését. Feladatát az alapító okiratban rögzített szentendrei székhellyel és a repülőmüszaki képzéseket megvalósító szolnoki telephellyel látja el, ahogy azt a jogelőd MH KPTSZI ${ }^{3}$ intézmény is végezte.

Az államilag elismert katonai Honvéd altiszt szakképesítés szakképzési feladatai mellett, az MH AA a honvéd altisztjelöltek és a legénységi állomány alapkiképzési, belső, a Magyar Honvédségben hasznosítható tanfolyamrendszerű képzési, nyelvi felkészítési és nemzetközi kiképzési feladatokat is folytat. A legénységi állomány alapkiképzési feladatait 2019 májusától már nem az MH AA végzi.

A cikk keretében az MH AA úgynevezett rövidített idejü altisztképzést átfogó 2017. szeptembertől 2019. júliusig terjedő időszak alatt elvégzett belső képzési rendszerü, tanfolyami keretek között folyó, a szerződéses legénységi állomány bázisára épülő altisztképzés eredményeit mutatom be és elemzem.

Az MH AA a szerződéses legénységi állomány belső képzését a Magyar Honvédség belső altisztképzési rendszerének átalakításáról és szabályozásáról szóló 309/2017. HVKF intézkedés ${ }^{4}$ alapján kezdte meg 2017 őszétől. Az első év tapasztalatai alapján a képzési forma szabályozását, nyilvántartását 2018 szeptemberétől a Magyar Honvédség belső altisztképzési rendszerének átalakításáról és szabályozásáról szóló 279/2018. HVKF intézkedéssel ${ }^{5}$ módosították.

A szolnoki telephely a rövidített idejü belső rendszerű tanfolyami altisztképzésben oktatást nem folytatott, a képzések kizárólag az MH AA Kinizsi Pál Altiszti Oktatási Osztály humánerőforrás-kapacitásának és a képzésbe bevont alakulatok személyi, technikai bázisán valósult meg.

A cikk nem foglalkozik az egyes tanfolyamok tanulmányi eredményének vizsgálatával, mert a képzési programokban a számonkérést a csökkentett képzési időhöz igazították, így a korábbi hasonló tanfolyamok eredményeitől szignifikáns eltérés nem volt tapasztalható.

A bemutatott képzési formát a Magyar Honvédség belső altisztképzési rendszeréről szóló 248/2019. MH PK intézkedéssel ${ }^{6} 2019$ augusztusában bevezetett, „Acélkocka” altisztképzési rendszer keretében megjelenő alap altiszti és az ezt követő szakmai tanfolyamrendszer váltotta fel.

\footnotetext{
Intézménykereső. Oktatási Hivatal. Elérhető: www.oktatas.hu/hivatali_ugyek/kir_intezmenykereso/!KIR_Intezmenykereso/Intezmeny/Index/100526 (A letöltés dátuma: 2020. 02. 12.)

MH KPTSZI: Magyar Honvédség Kinizsi Pál Tiszthelyettes Szakképző Iskola.

4 + 6 hetes képzésként emlegetett képzési forma. Négy hét alaptanfolyamot és kimenettől függően 6-8 hét szakmai képzést foglalt magában. A műszaki képzés volt a leghosszabb, 11 hetes. 309/2017. (HK 9.) HVKF intézkedés a Magyar Honvédség belső altisztképzési rendszerének átalakításáról és szabályozásáról.

5 279/2018. (HK 9.) HVKF intézkedés a Magyar Honvédség belső altisztképzési rendszerének átalakításáról és szabályozásáról.

6 248/2019. (HK 7.) MH PK intézkedés a Magyar Honvédség belső altisztképzési rendszeréről.
} 


\section{A rövidített idejü altisztképzés bevezetése, szerkezete}

A rövidített idejü altisztképzés, a Magyar Honvédség belső tiszthelyettes képzési rendszerének bevezetéséről szóló 528/2011. HVKF intézkedés ${ }^{7}$ szerinti képzést váltotta fel.

A korábbi - leváltott - tiszthelyettes képzés két részből állt: a) Tiszthelyettesi alaptanfolyam (3 hónap); b) Szakmai tanfolyam (2-6 hónap).

A tiszthelyettes alaptanfolyamot a tanév őszi időszakában szervezték meg, majd ezt követően a tavaszi félévben a szakmai tanfolyamokat. A szakmai tanfolyam pontos időtartamát és tartalmát a kiadott programok határozták meg 2-6 hónap terjedelemben.

A fent vázolt tiszthelyettesképzés alapvetően hosszú volt, és nem tudta a megfelelő kibocsátási létszámot biztosítani, ezért vált szükségessé a rövidített, jellemzően $4+6$ hetes $^{8}$ képzési rendszer bevezetése.

A rövidített idejű altisztképzést 2017 szeptemberétöl indították, amellyel a korábbi éves forgási ciklus, azaz alap- és szakmai tanfolyam megszervezése, féléves ciklusra szükült, aminek eredményeként a kibocsátási létszám növekedhetett.

Az új altisztképzést a Magyar Honvédség belső altisztképzési rendszerének átalakításáról és szabályozásáról szóló 309/2017. HVKF intézkedés vezette be, majd 2018 szeptemberétől kezdődően a képzési tapasztalatok alapján, a 279/2018. HVKF intézkedés módosította.

A képzés két nagy blokkból: a) 4 hetes altiszti alaptanfolyamból, b) és az ezt követő különböző hosszúságú altiszti szakmai képzésekből (6-11 hét) tevődött össze.

Az új rövidített altisztképzési rendszer kimeneteit az 1. táblázatban láthatjuk:

1. táblázat: Az altisztképzési rendszer kimenetei, óraszámai.

\begin{tabular}{|c|c|c|}
\hline Ssz. & Az altiszti alap- és szaktanfolyam megnevezése & Képzés ideje \\
\hline 1. & Altiszti alaptanfolyam & 4 hét (124 óra) \\
\hline 2. & $\begin{array}{c}\text { Híradó altiszti szaktanfolyam, Átvitel- és kapcsolástechnikai eszközüzemel- } \\
\text { tetö szakirány }\end{array}$ & 8 hét (294 óra) \\
\hline 3. & Híradó altiszti szaktanfolyam, Rádióállomás üzmeltetö szakirány & 8 hét (294 óra) \\
\hline 4. & Élelmezési ellátó & 8 hét (240 óra) \\
\hline 5. & Ruházati ellátó & 8 hét (240 óra) \\
\hline 6. & Üzemanyag-ellátó & 8 hét (240 óra) \\
\hline 7. & Közlekedés-szállitás & 7 hét (224 óra) \\
\hline 8. & Harckocsizó & 7 hét (266 óra) \\
\hline 9. & Lövész & 7 hét (272 óra) \\
\hline 10. & Páncéltörötüzér & 7 hét (228 óra) \\
\hline 11. & Vegyivédelmi & 8 hét (252 óra) \\
\hline 12. & Tábori tüzér & 7 hét (228 óra) \\
\hline
\end{tabular}

528/2011. (HK 12.) HVKF intézkedés a Magyar Honvédség belső tiszthelyettes képzési rendszerének bevezetéséről. A programban szereplő vizsgahetet nem számolva, tiszta felkészítési időtartam. 


\begin{tabular}{|c|c|c|c|}
\hline Ssz. & \multicolumn{2}{|c|}{ Az altiszti alap- és szaktanfolyam megnevezése } & Képzés ideje \\
\hline 13. & \multicolumn{2}{|c|}{ Tüzér felderitö, bemérö, tüzvezetö } & 7 hét (238 óra) \\
\hline \multirow{3}{*}{14.} & \multirow{3}{*}{ Korona, palotaör, illetve díszelgő } & Koronaör & 7 hét (266 óra) \\
\hline & & Palotaör & 6 hét (235 óra) \\
\hline & & Díszelgö & 6 hét (235 óra) \\
\hline 15. & \multicolumn{2}{|c|}{ Lokátor állomásparancsnok } & 9 hét (288 óra) \\
\hline 16. & \multicolumn{2}{|l|}{ Müszaki } & 11 hét (308 óra) \\
\hline 17. & \multicolumn{2}{|c|}{ Altiszti katonai rendész } & 8 hét (282 óra) \\
\hline 18. & \multicolumn{2}{|c|}{ Ügykezelö (Ügyvitel) } & 8 hét (222 óra) \\
\hline
\end{tabular}

Forrás: a szerző szerkesztése

A szakmai képzés időtartamának csökkenése a megtanitható ismeretekre is hatással volt, ezért a képzési idő csökkenését a bemeneti követelményként elöírt kötelező szakmai tapasztalat volt hivatott ellensúlyozni.

A bemeneti követelmények között a korábbi tiszthelyettes alaptanfolyam esetében előírt szakaszvezető (2014 decemberét követően tizedes) rendfokozatot, az új képzési rendben őrvezetői rendfokozat és 3 év szolgálati idő váltotta fel. A képzést bevezető intézkedés 2018 nyarán történt módosításával, a speciális szakképzettségek meglétéhez kötött munkakörök esetében a szakmai területért felelős szervezet támogató véleménye alapján legkevesebb 1 év szolgálati idő alatt megszerzett szakmai tapasztalat jelent meg követelményként. Az elvárt szakmai tapasztalat idejének folyamatos csökkentése alapján csak feltételezhető, hogy erre a beiskolázási létszám szinten tartása miatt volt szükség.

Már a kezdeteknél feszültségként jelentkezett, hogy a képzés kizárólag a szerződéses legénységi állomány bázisára épül, így a hiányt az egyik állománykategóriából a másikba helyezte át. Ez a hatás még akár eredményesnek is lett volna mondható, ha az altiszti állománykategória esetében a kiáramlás megállt volna. Sajnos ennek ellenkezőjére enged következtetni a 18 hetes Acélkocka altiszti alaptanfolyam, amely bázisát tekintve a civil életből toboroz, és a korábbi beiskolázáshoz képest jelentősen nagyobb, egyszerre 250 főt vont be a képzésbe.

Kizárólag a Tábori tüzér szakmai altiszti tanfolyam esetében írtak elö és dolgoztak ki egy előzetes tudásszintfelmérőt, amelynek eredményes teljesítését a szakmai tanfolyam megkezdésének feltételeként, bemeneti követelményként rögzítették. Sajnálatos módon előfordult olyan eset, hogy vezetői döntés eredményeként olyan személy kezdte meg a tanfolyamot, aki az előzetes tudásfelmérést nem teljesítette eredményesen.

A bevezetett képzés rövid időtartamára tekintettel, a rövidített idejü altisztképzést egyedül a felderítő fegyvernem nem vezette be, ők továbbra is a korábbi képzési programjuknak megfelelően hajtották végre a felkészítést 16 hét (458 óra) időtartamban. 


\section{Képzési adatok}

A képzési adatokat két tanév a 2017/2018 és a 2018/2019 tanévek őszi és tavaszi féléveinek, azaz négy félév vonatkozásában elemzem és mutatom be.

\subsection{7. őszi képzés adatai}

\subsubsection{Altiszti alaptanfolyam}

A képzést a nagy létszámra tekintettel három helyszínen, Szentendrén az MH AA-n 108 fővel, Szolnokon az MH 2. vitéz Bertalan Árpád Különleges Rendeltetésű Dandárnál 38 fövel és Debrecenben, az MH 5. Bocskai István Lövészdandárnál 49 fővel hajtotta végre az MH AA. Összesen 195 fő kezdte meg a tanfolyamot és a szolnoki 3 fö lemorzsolódását követően 192 fö kezdhette meg a tanfolyami vizsgát.

Az írásbeli vizsgára 192 fő volt bocsátható. A 192 főből 9 főnek nem sikerült teljesíteni az írásbeli vizsgát az előírt minimum 60\%-ra. A vizsgát nem teljesítőket a következő altiszti alaptanfolyam utolsó 2 hetére iskolázták be, majd ezt követően eredményes vizsgát tettek.

Az ábrán (1. ábra) látható, hogy csak az MH 2. vitéz Bertalan Árpád Különleges Rendeltetésü Dandárnál Szolnokon keletkezett 3 fö lemorzsolódás, amely a tanfolyam ideje alatt, saját kérelemre történt meg.

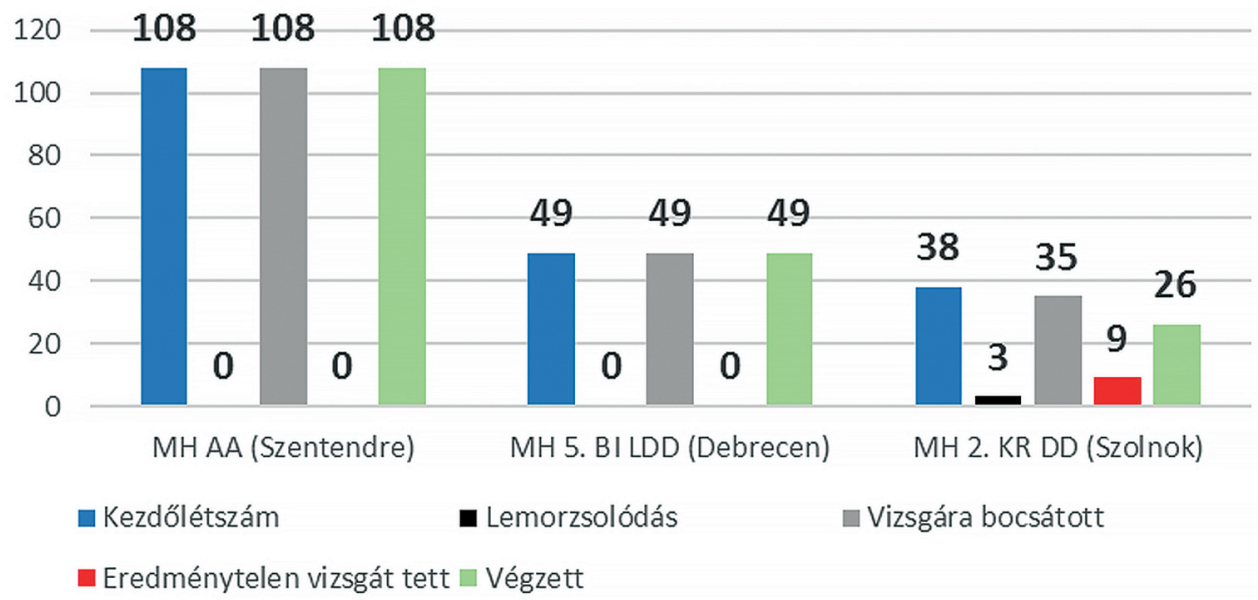

1. ábra: Az első röviditett altiszti alaptanfolyam létszámadatai.

Forrás: a szerző szerkesztése 


\subsubsection{Altiszti szakmai tanfolyamok}

A szakmai képzést 13 kimeneten 144 fő kezdőlétszámmal kezdte meg az MH AA és a Tábori tüzér képzésen történt 5 fö lemorzsolódás miatt, 139 fö végzett és volt vizsgára bocsátható.

Az előző rendszerü képzésben szervezett tiszthelyettesi műszaki szakmai tanfolyam vizsgakörnyezetének szabályozását leíró 528/2011. HVKF intézkedés ${ }^{9} 4.5$. pontjában és a korábbi képzés programjának IX. fejezetében foglaltak alapján - „Eredménytelen vizsgarész egy alkalommal ismételhető a vizsgabizottság döntése alapján." - 1 fő pótvizsgára jelentkezett, ezért az érintett személyt beiskolázták a müszaki tanfolyamra. A 2. ábra és a 3. ábra ezt a személyt nem pótvizsgázónak, hanem tanfolyamot kezdő létszámként kezeli. Az érintett személy az ismételt írásbeli vizsgán is elégtelen eredményt ért el, így megbukott, ezért a szabályozásra tekintettel, több alkalommal vizsgát már nem ismételhetett.

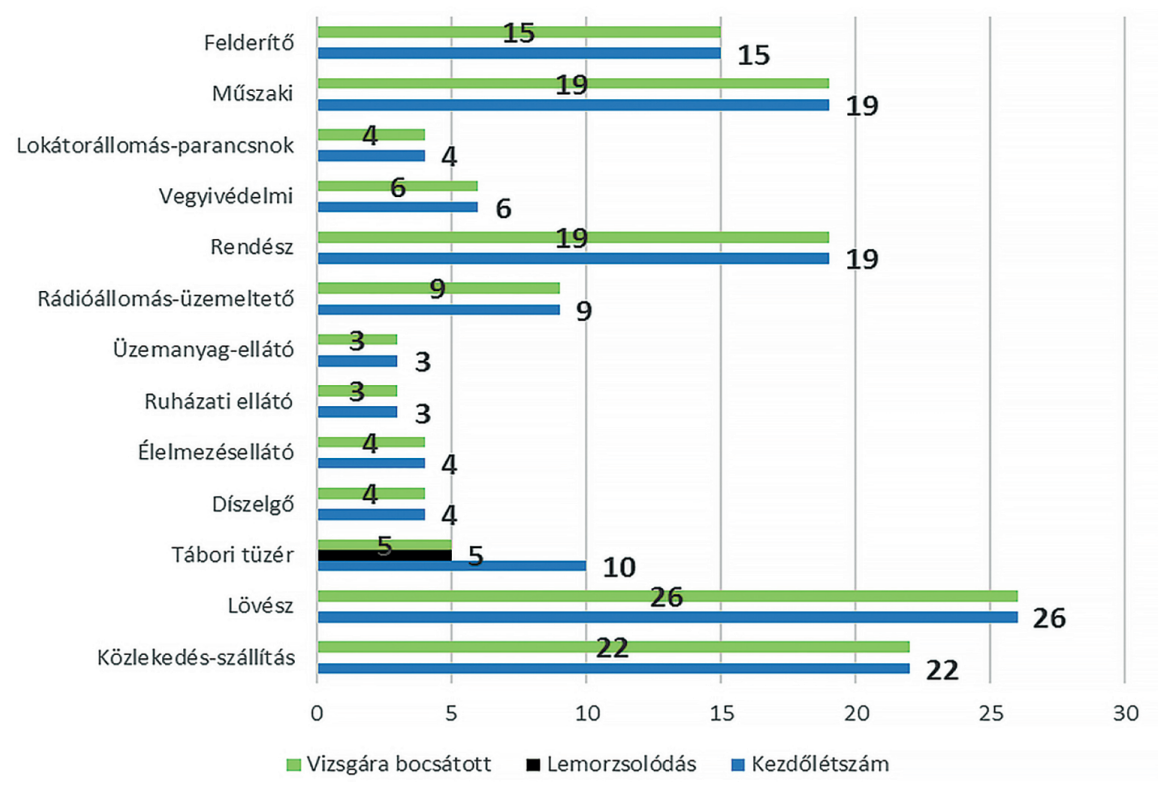

2. ábra: Altiszti szakmai tanfolyamok létszámadatai-2017. ösz.

Forrás: a szerző szerkesztése

A szakmai tanfolyamok során az eredménytelenül vizsgázó 6 föt és a 2 fő időszakon belül eredményesen pótvizsgázót számolva, összesen 135 fő tett eredményes vizsgát ebben az időszakban. A 2. ábra által jelzett lemorzsolódás a tanfolyamról kiesettek létszámát jelöli.

9 528/2011. (HK 12.) HVKF intézkedés a Magyar Honvédség belső tiszthelyettes képzési rendszerének bevezetéséről. 


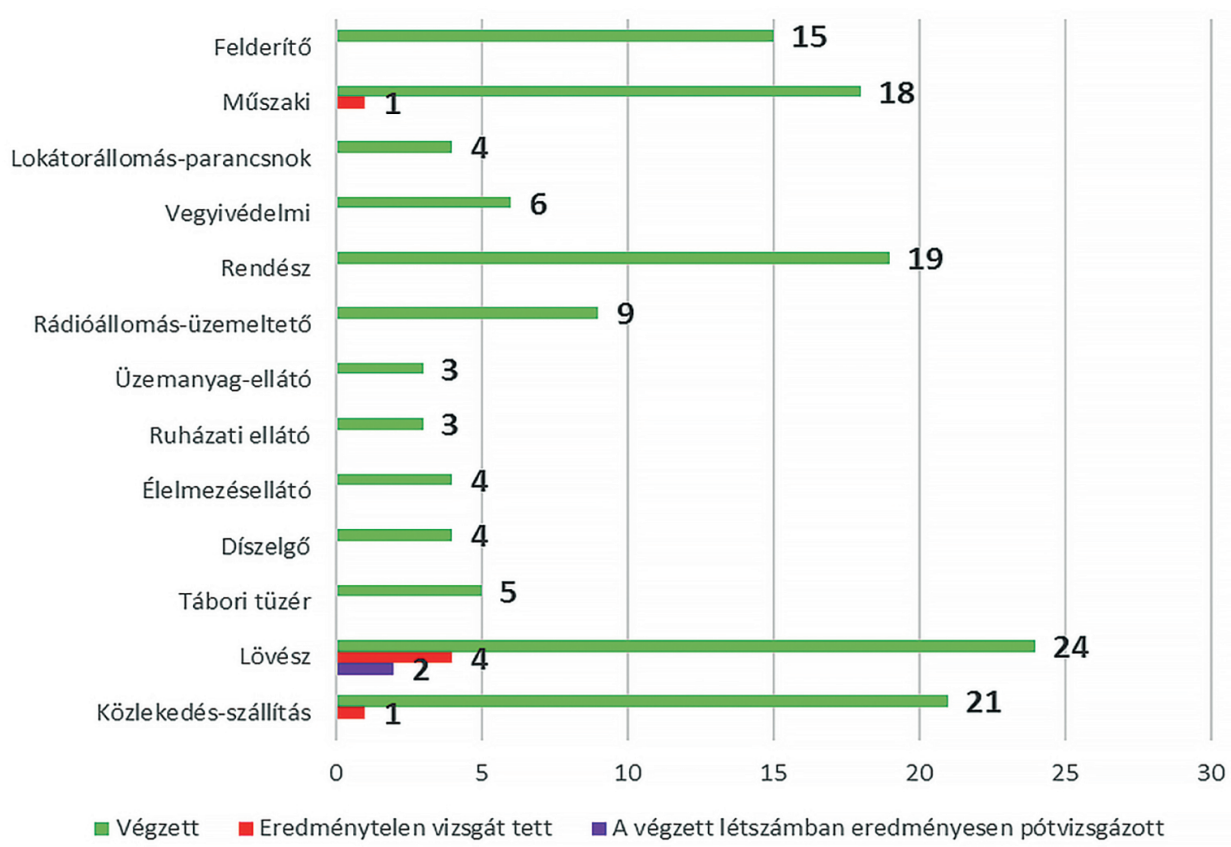

3. ábra: Altiszti szakmai tanfolyamok vizsgaadatai-2017. ősz.

Forrás: a szerző szerkesztése

A Közlekedés-szállítás altiszti szaktanfolyamon részt vevők képzését a 2017. október 2-a és 2017. november 17-e közötti időintervallumban hajtották végre. A beiskolázott 23 föből 22 fő vehetett részt a tanfolyamon, mert 1 fö korábban már megbukott az altiszti alaptanfolyam vizsgán. A képzésen részt vevők közül 1 fő bukott meg a vizsga során (írásbelin és szóbelin), ezért 21 fő az, aki eredményesen teljesítette a tanfolyami vizsgát. A két vizsgatevékenységből történő bukásra tekintettel az érintett 1 fő a következő tanfolyami ciklusban kapott pótvizsga-lehetőséget, aki a következő ismételt vizsgán eredményesen teljesített.

Az Altiszti szaktanfolyam Lövész szakirányon részt vevők képzése a 2017. október 2-a és 2017. november 17-e közötti időintervallumban történt. A beiskolázásban szereplő 27 főből 26 fő vehetett részt a képzésben, mert 1 fő korábban már megbukott az altiszti alaptanfolyam vizsgáján. A részt vevő 26 főből 4 fő nem teljesítette bukás miatt a tanfolyamot, így igazolást nem kaptak. Az írásbelin bukott 4 főből 2 fő részére még képzési cikluson belül 2017. december 11-én volt lehetőség az írásbeli vizsga javítására, amelyet a javító vizsgázók eredményesen teljesítettek. A gyakorlati vizsgarészen elégséges szintet el nem ért 2 fö részére - a vizsga bonyolultabb dokumentációs, szervezési és humánerőforrás-igényére tekintettel - a következő tanfolyami ciklusban biztosított az MH AA pótvizsga-lehetőséget. A következő ciklusban javítók később eredményes vizsgát tettek. 
A Tábori tüzér altiszti szaktanfolyamon részt vevők részére a képzést 2017. október 2-a és 2017. november 17-e között tartották. A beiskolázott 10 föböl 4 föt visszavezényeltek alakulatához, mert a tervezett beosztásukhoz nem a megfelelő tanfolyamra lettek beiskolázva. Hiányzás miatt a tanfolyam során 1 föt visszavezényeltek, mert betegség miatt meghaladta a hiányzása a programban engedélyezhető $10 \%$-ot. A szaktanfolyamot befejező 5 fö eredményesen levizsgázott.

Díszelgő altiszti szakmai tanfolyamra 5 föt iskoláztak be, de 1 fö megbukott az altiszti alaptanfolyamon, ezért a 2017. október 2-a és 2017. november 24-e között végrehajtott képzésen 4 fő vehetett csak részt. A képzésben részt vevők eredményesen teljesítették a tanfolyami vizsgát.

Az Élelmezésellátó, Ruházati ellátó, Üzemanyag-ellátó, Rádióállomás-üzemeltető és Vegyivédelmi altiszti szaktanfolyamon, továbbá a Lokátorállomás-parancsnok szakmai altiszti tanfolyamon végzettek eredményes vizsgát tettek.

Az Altiszti katonai rendész szakmai modult 2017. október 2-a és 2017. november 24-e között folytatták le. A tervezett 20 föből 1 fö megbukott az altiszti alaptanfolyamon, ezért nem jelenhetett meg a szaktanfolyamon. A képzésen részt vevő 19 fő eredményesen levizsgázott.

Az ábrán látható (3. ábra) Müszaki tanfolyam adatai esetében 19 fő volt beiskolázásra tervezve. A tanfolyamot az altiszti alaptanfolyamon megbukott egy fő csökkentéssel és az előző tiszthelyettesi müszaki szaktanfolyamból pótvizsgázó és tanfolyamra kötelezett 1 fővel 19 fő kezdte meg. A pótvizsgázó ismételten megbukott, így a müszaki tanfolyam eredményes vizsgázóinak száma 18 fö lett.

A Felderítő altiszti tanfolyamot az MH AA 2017. október 2-a és 2018. január 26-a között hajtotta végre a korábbi, azaz nem a rövidített program alapján. A tanfolyamon végzett 15 fö eredményes vizsgát tett.

\subsection{8. tavaszi képzés adatai}

\subsubsection{Altiszti alaptanfolyam}

A képzést 2018. február 5. és március 2. között hajtotta végre az MH AA. Az előző ciklusban eredménytelenül vizsgázó 9 fő csatlakozott a képzéshez, így 125 fő képzési létszám jelent meg a tanfolyamon. Mind a 125 fö eredményesen vizsgázott az alaptanfolyam vizsgáján.

\subsubsection{Altiszti szakmai tanfolyamok}

A képzést 10 kimeneten 94 fö kezdölétszámmal, a Lövész 2 fö, továbbá a Közlekedésszállítás altiszti szakmai tanfolyamon történt 1 fö lemorzsolódás miatt 91 fővel fejezte be az MH AA és 91 fö volt vizsgára bocsátható (4. ábra). 


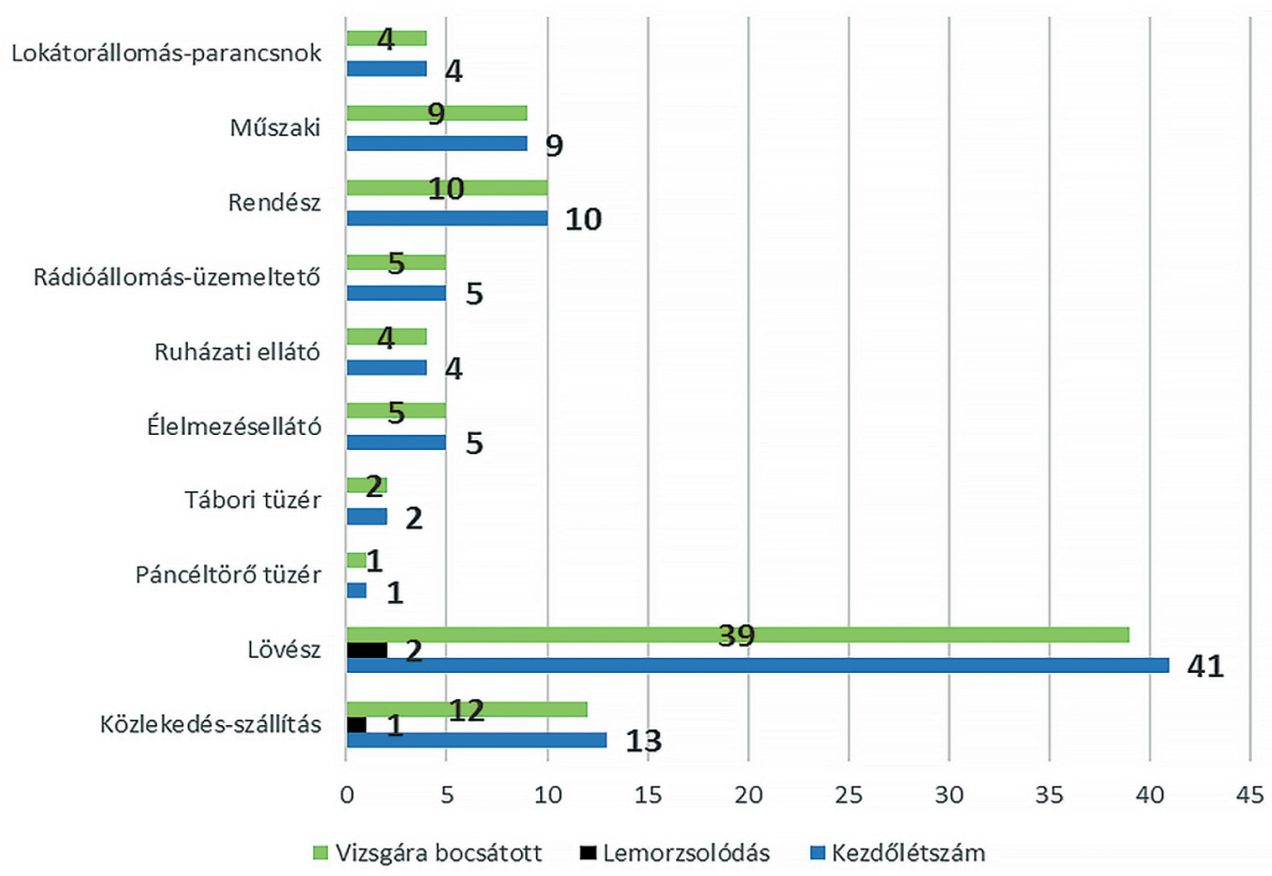

4. ábra: Altiszti szakmai tanfolyamok létszámadatai-2018. tavasz.

Forrás: a szerző szerkesztése

A Lövész szakmai vizsgát egy fö teljesítette eredménytelenül. A Lövész tanfolyamba becsatlakozva 2 fő pótvizsgázó eredményes pótvizsgát tett, így ebben az időszakban összesen 90 fő tett eredményes vizsgát.

Közlekedés-szállítás altiszti szaktanfolyamon a képzést 2018. március 5. és 2018. április 27. között hajtották végre. A beiskolázott 13 föből 12 fö vett részt a képzésen. 1 fő családi okok miatt nem kezdte meg a tanulmányait.

Lövész altiszti szakmai tanfolyamon a képzést 2018. március 5. és 2018. április 27. között tartották. A képzésre az előző ciklusban gyakorlati vizsgán eredménytelenül teljesítő 2 fövel együtt 41 fő volt tervezve beiskolázásra. A tanfolyamon 2 fö nem jelent meg, így 39 fő kezdte meg a tanfolyamot. A képzésben részt vevők közül 1 fő bukott meg a vizsga során (szóbelin és gyakorlatin). A többiek eredményes vizsgát tettek. A két tevékenységből történő bukásra tekintettel a következő tanfolyami ciklusban biztosított az MH AA pótvizsga-lehetőséget az eredménytelenül vizsgázónak, aki később az ismételt lövész szakmaitanfolyam-vizsgán nem jelent meg. 


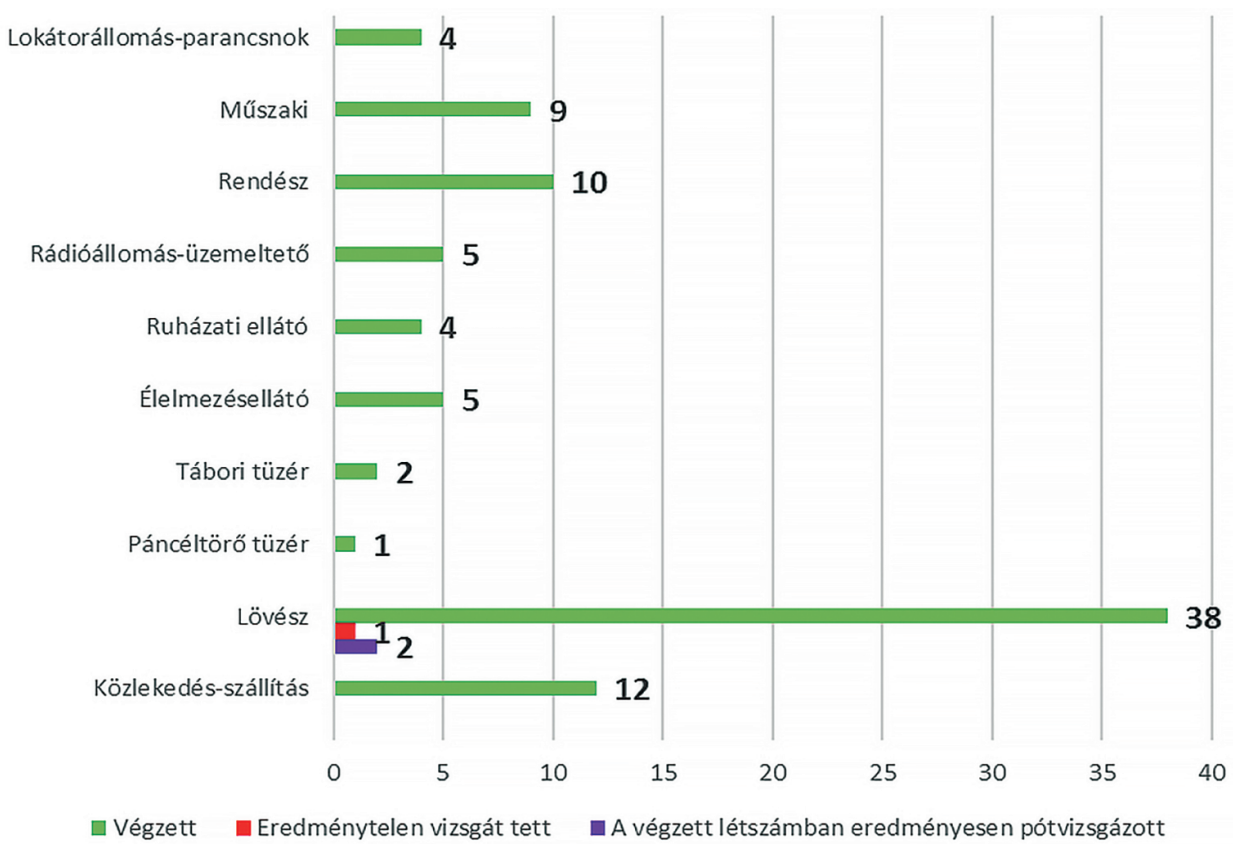

5. ábra: Altiszti szakmai tanfolyamok vizsgaadatai-2018. tavasz.

Forrás: a szerző szerkesztése

A Páncéltörő tüzér altiszti szaktanfolyamon a képzést 2018. március 5. és 2018. április 27. között tartották meg. A képzést a MH 25. Klapka György Lövészdandárnál hajtották végre 1 fő részvételével. A képzésen részt vevő eredményes vizsgát tett.

A Tábori tüzér altiszti szaktanfolyamon a képzést 2018. március 5. és 2018. április 27. között tartották meg. A képzést a MH 25. Klapka György Lövészdandárnál hajtották végre 2 fö részvételével. A képzésen részt vevők eredményes vizsgát tettek.

Altiszti katonai rendész szakmai modulon a képzést 2018. március 5. és 2018. május 4. között hajtották végre. A beiskolázott 10 fö eredményes vizsgát tett.

A Müszaki altiszti szaktanfolyamon a képzést 2018. március 5. és 2018. május 18. között tartották meg. A tanfolyamra 9 föt iskoláztak be, lemorzsolódás nem volt. A beiskolázott 9 fö eredményesen teljesítette a tanfolyami vizsgát.

Lokátorállomás-parancsnoki altiszti szaktanfolyamon a képzést 2018. március 5. és 2018. május 25. között tartották. A tanfolyamra 4 föt iskoláztak be, lemorzsolódás nem volt. A képzésben részt vevők eredményesen teljesítették a tanfolyami vizsgát.

Az ábrán (5. ábra) látható többi tanfolyam esetében a tanfolyamot befejező vizsgára bocsátott végzős létszám mindegyik esetben eredményes vizsgát tett. 


\subsection{8. őszi képzés adatai}

\subsubsection{Altiszti alaptanfolyam}

A képzést 2019. szeptember 3-a és szeptember 28-a között 146 fő képzési létszámmal hajtotta végre az MH AA. A résztvevők közül 143 fő eredményesen teljesítette a képzést. A tanfolyamról 3 föt vezényeltek vissza az alakulatához, az MH 25. Klapka György Lövészdandárhoz, mert hiányzásuk mértéke meghaladta a programban engedélyezett maximális értéket.

A vizsgák végrehajtása 2018. szeptember 28 -án történt meg. Az írásbeli vizsgára 143 fő volt bocsátható. A 143 főből két fönek nem sikerült eredményes vizsgát tennie, azaz 141 fő fejezte be a tanfolyamot eredményesen. A két főből később egy fő jelent meg a következő képzésben szervezett pótvizsgán, amit akkor eredményesen teljesített. Ez az egy fő később a lövésztanfolyamot kezdte meg, amit nem tudott eredményesen teljesíteni.

\subsubsection{Altiszti szakmai tanfolyamok}

A szakmai képzésben 13 kimeneten 101 fő kezdőlétszám jelent meg. A Rendész 2 fő, továbbá a Páncéltörő tüzér és a Lövész altiszti szakmai tanfolyamon történt 1-1 fö lemorzsolódás miatt 97 fő vizsgázott.

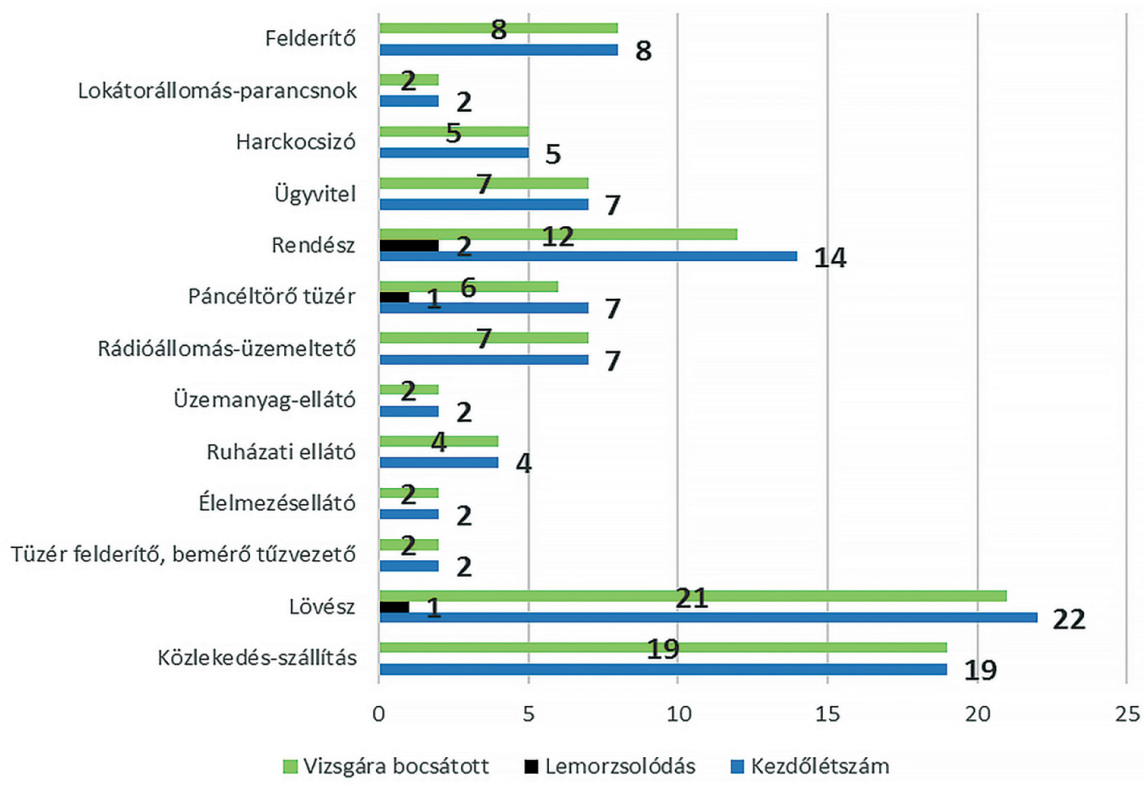

6. ábra: Altiszti szakmai tanfolyamok létszámadatai-2018. ősz.

Forrás: a szerző szerkesztése 
A tanfolyamot eredményesen teljesítő és vizsgára bocsátott létszámból az Ügyvitel és a Harckocsizó szakmai tanfolyamon történt bukás miatt 95 fö tett eredményes vizsgát.

Lövész altiszti szakmai tanfolyamon a képzésre 22 fö volt beiskolázásra tervezve, de az említett 2018-as őszi alaptanfolyami vizsgán történt bukás miatt a tanfolyamot 1 fő nem kezdhette meg, amelyet lemorzsolódásként jelez a 6 . ábra. A tanfolyamot teljesítő 21 fő eredményes vizsgát tett.

Páncéltörő tüzér altiszti szaktanfolyamon a képzést 2018. október 1. és 2018. november 23. között tartották meg. A tanfolyamra 7 fő volt beiskolázásra tervezve. Egy fő sikertelen bemeneti vizsgát tett, így a tanfolyamot nem kezdhette meg, a 6. ábra az érintett személyt lemorzsolódásként kezeli. A tanfolyamot teljesítő és vizsgára bocsátott 6 fö eredményes vizsgát tett.

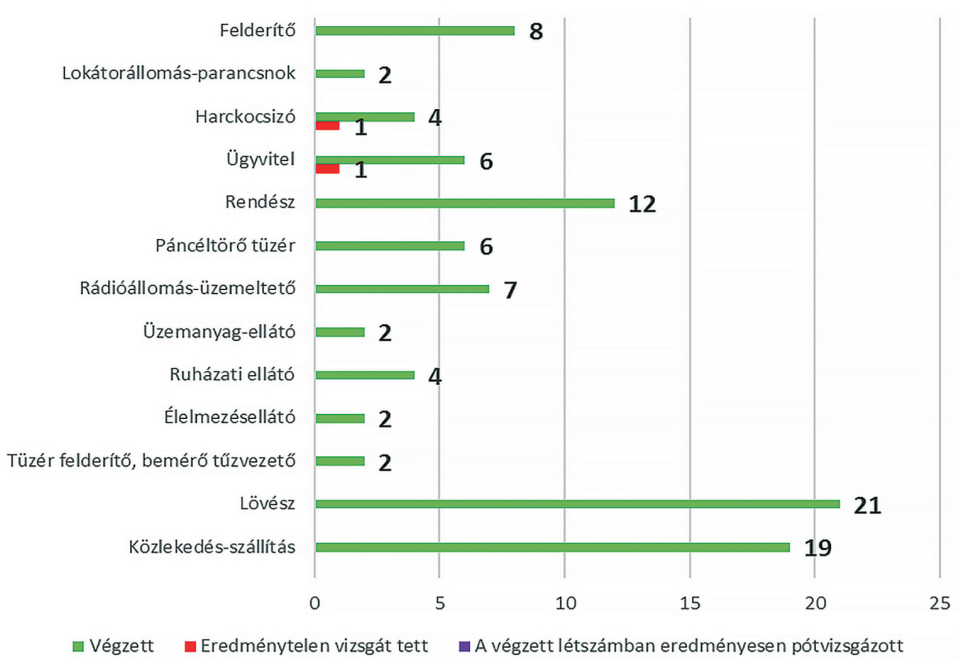

7. ábra: Altiszti szakmai tanfolyamok vizsgaadatai -2018. ösz.

Forrás: a szerző szerkesztése

Altiszti katonai rendész szakmai modulon a képzést 2018. október 1. és 2018. november 23. között tartották meg. A beiskolázásra tervezett 14 főböl nem a tanfolyamon történt baleset miatt 2 fő maradt ki a képzésböl. A tanfolyamot teljesítő és vizsgára bocsátott 12 fö eredményes vizsgát tett.

Az Ügykezelő (ügyvitel) tanfolyamot 7 fö kezdte meg, amelyből mindenki vizsgára bocsátható volt, de a szakmai tanfolyam vizsgáját 1 fő eredménytelenül teljesítette, amit a 7. ábra eredménytelen vizsgázóként kezel.

A Harckocsizó szakmai tanfolyamot 2018. október 1. és 2018. november 30. közötti időszakban 5 fö részvételével hajtották végre. A tanfolyamon 4 fö tett eredményes vizsgát. Az eredménytelenül vizsgázó személy részére 2019. február 5-én a következő ciklusban szerveztünk pótvizsgát, amit eredményesen teljesített.

Az ábrán (7. ábra) jelzett többi tanfolyam esetében a végzős létszámban szereplők eredményes vizsgát tettek. 
A felderítő képzés ebben az időszakban is a korábbi, hosszabb idejű képzési programja szerint, a 2018. október 1. és 2019. január 25. közötti időszakban folytatta a képzést. Ennek keretében a vizsgákon 8 fő tett eredményes vizsgát.

\subsection{9. tavaszi képzés adatai}

\subsubsection{Altiszti alaptanfolyam}

A tanfolyamot 2019. február 4. és március 1. között hajtotta végre az MH AA 157 fő tervezett képzési létszámmal, amelyből 2 fő családi okok miatt nem kezdte meg a képzést, így 155 fö tett eredményes vizsgát.

\subsubsection{Altiszti szakmai tanfolyamok}

A képzést 10 kimeneten 121 fő létszámmal kezdte meg az MH AA és a Lövész 1 fő, továbbá a Müszaki, Ruházati ellátó, Közlekedés-szállítás és a Rádióállomás-üzemeltető szakmai tanfolyamon történt 2-2-2-2 fö lemorzsolódás miatt 112 fö vizsgázott a tanfolyamok befejezését követően. Az előző ciklusban a Harckocsizó altiszti szakmai tanfolyam keretében eredménytelenül vizsgázott személy részére kizárólag csak pótvizsgát szerveztünk, amelyet eredményesen teljesített. A pótvizsgázó személylyel együtt, 113 fö tett a ciklusban altiszti szakmai tanfolyami vizsgát. A 2 fö Lövész szakmai altiszti tanfolyamon történt bukás miatt összesen 111 fö volt az, aki ebben az időszakban a szakmai tanfolyamok vizsgáinak keretében eredményes vizsgát tett.

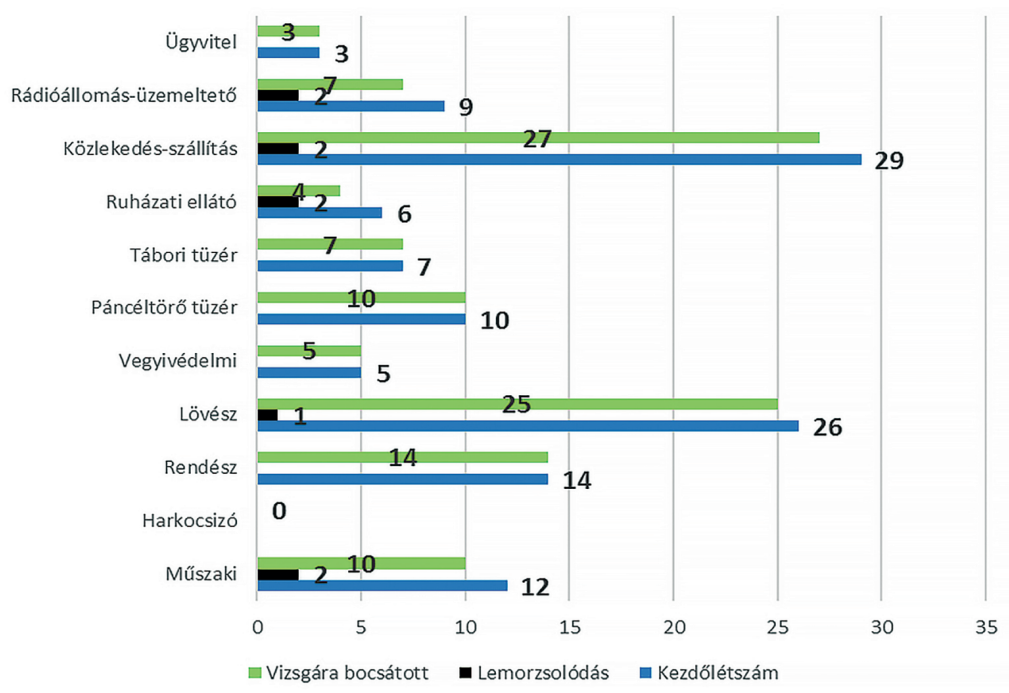

8. ábra: Altiszti szakmai tanfolyamok létszámadatai - 2019. tavasz.

Forrás: a szerző szerkesztése 
A Müszaki altiszti szaktanfolyamon a képzés 2019. január 7. és 2019. március 14. között zajlott le. A tanfolyamra 12 föt iskoláztak be, 2 fö nem jelent meg a képzésen, amely két főt az ábra (8. ábra) lemorzsolódásként jelenít meg. A tanfolyamot teljesítő, végzett 10 fö eredményesen levizsgázott.

A Harckocsizó tanfolyamot nem folytatták le, csak az előző ciklusban eredménytelenül vizsgázott személy részére szervezett az MH AA altiszti szakmai tanfolyami pótvizsgát, amelyet az érintett eredményesen teljesített. A 8. ábra ezért a Harckocsizó tanfolyam létszámát nulla fő tanfolyami létszámmal jeleníti meg.

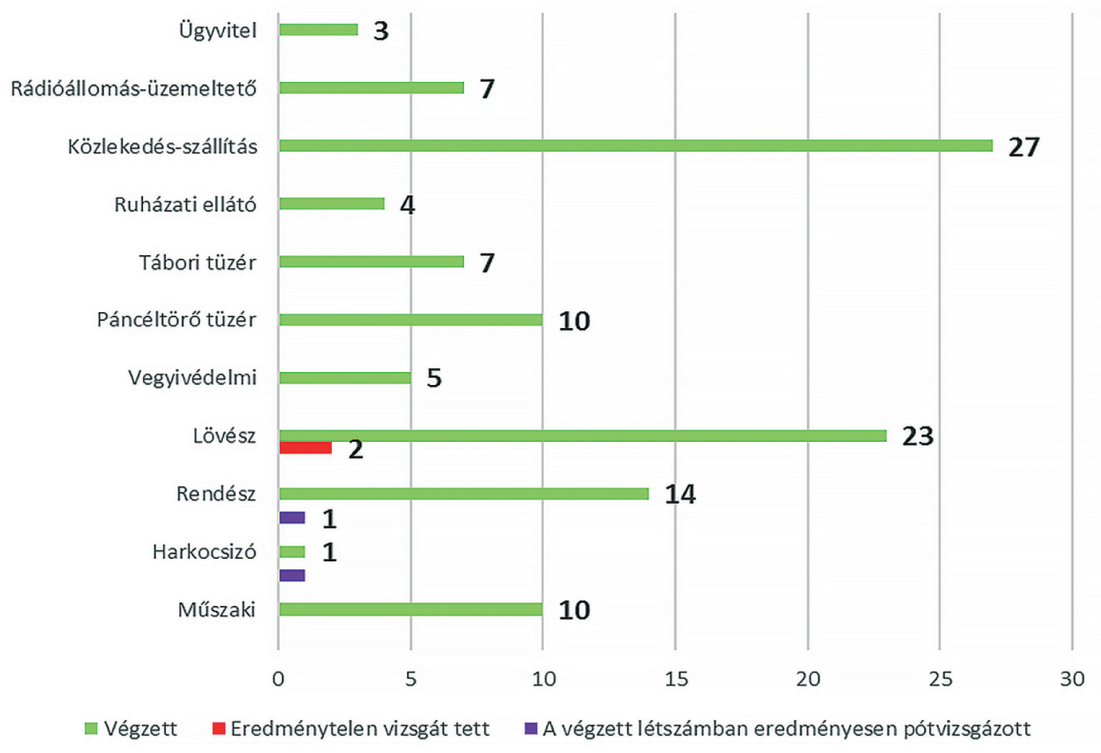

9. ábra: Altiszti szakmai tanfolyamok vizsgaadatai -2019. tavasz.

Forrás: a szerző szerkesztése

A Rendész szakmai altiszti tanfolyamot a 2019. március 4. és 2019. május 3. közötti időintervallumban hajtották végre. A beiskolázott 13 fő és 1 fő pótvizsgázó eredményesen teljesítette a vizsgakövetelményeket. A 8. ábra és a 9. ábra mind a 14 föt kezdő és végzős létszámként is egyaránt kezeli.

A Lövész szakmai altiszti tanfolyamot a 2019. március. 25. és 2019. május 24. közötti időintervallumban hajtották végre. A beiskolázott 26 főből 25 fő vett részt a képzésen. A szakmai vizsgán történt 2 fö bukás miatt 23 fö teljesítette eredményesen a vizsgáztatási követelményeket.

A Ruházati ellátó szakmai altiszti tanfolyamot a 2019. május 1. és 2019. május 31. közötti időintervallumban 6 fövel tervezték, amelyböl 2 fö nem jelent meg a tanfolyamon, ezért a tanfolyamot 4 fövel hajtották végre. A beiskolázottak eredményes vizsgát tettek, a 2 föt lemorzsolódásként kezeli az ábra (8. ábra). 
A Közlekedés-szállítás szakmai altiszti tanfolyamot a 2019. április 1. és 2019. május 31. közötti időintervallumban 29 fővel tervezték, amelyből egy fő nem jelent meg, egy fö pedig nem teljesítette az alaptanfolyamot, így azt 27 fővel hajtották végre. A beiskolázottak eredményes vizsgát tettek.

A Rádióállomás-üzemeltető altiszti tanfolyamot a 2019. április 29. és 2019. június 28. közötti időintervallumban hajtották végre. A beiskolázásra tervezett 9 fő helyett 7 fő jelent meg a képzésen. A megjelentek eredményes vizsgát tettek, a 2 főt lemorzsolódásként kezeli az ábra (8. ábra).

A 9. ábrán jelzett többi tanfolyam esetében a végzős létszámban szereplők eredményes vizsgát tettek.

\section{4. Összesített adatok (2017-2019)}

\subsection{Altiszti alaptanfolyamok}

A két év alatt 8 fő lemorzsolódás és 11 fő bukás mellett, 623 főből 604 fő fejezte be eredményesen az altiszti alaptanfolyamot.

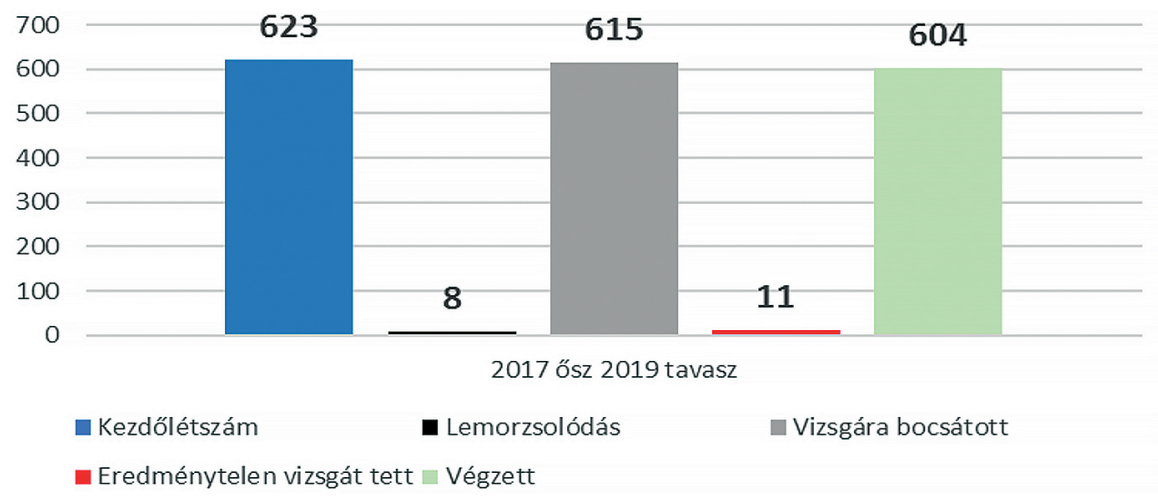

10. ábra: Az altiszt alaptanfolyamok összesített létszámadatai (2017-2019).

Forrás: a szerző szerkesztése

\subsection{Altiszti szakmai tanfolyamok}

A vizsgált időszakban 17 féle típusú altiszti szakmai tanfolyamból $46 \mathrm{db}$ tanfolyamot és $1 \mathrm{db}$ egy fö részére megszervezett Harckocsizó altiszti szakmai tanfolyami pótvizsgát hajtottak végre, amelyeken összesen 460 fö vett részt. A 29 fő eredménytelen vizsga és lemorzsolódás mellett 431 fö fejezte be eredményesen a különböző képzéseket. A tanfolyamonkénti összesített létszámadatokat mutatja be a 11. ábra. 

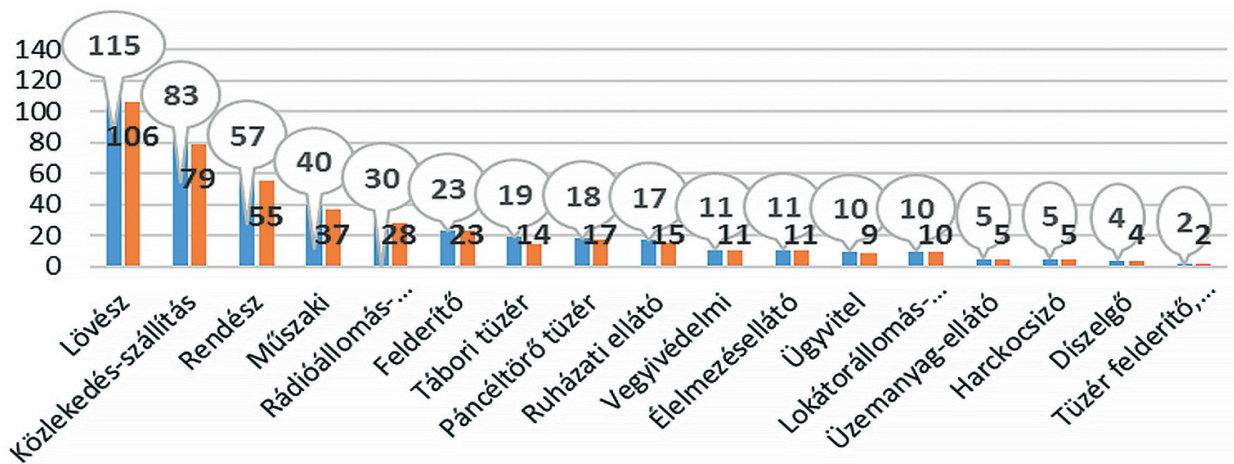

$\square$ Kezdőlétszám $\square$ Tanfolyamot eredményesen befejezte

11. ábra: Altiszti szakmai tanfolyam összesített létszámadatok tanfolyami bontásban (2017. ösz - 2019. tavasz). Forrás: a szerző szerkesztése

\subsubsection{Tanfolyamok száma képzési bontásban (2017. ösz - 2019. tavasz)}

Öt tanfolyam esetében minden ciklusban szerveztünk képzést. A Díszelgő, a Harckocsizó, a Tüzér felderítő, bemérő tűzvezető tanfolyamból a négy ciklus alatt csak egy-egy tanfolyamot hajtottak végre. Olyan képzési forma is szerepelt az új rendszerü altiszti szakmai tanfolyamok között, amelyekből egy képzést sem szerveztek meg (Koronaőr, Palotaőr, Átvitel- és kapcsolástechnikai eszközüzemeltető). A többi kimenet esetében a vizsgált időszakban kettő vagy három tanfolyamot szervezett az MH AA. A végrehajtott tanfolyamok számosságát a 12. ábra mutatja be.

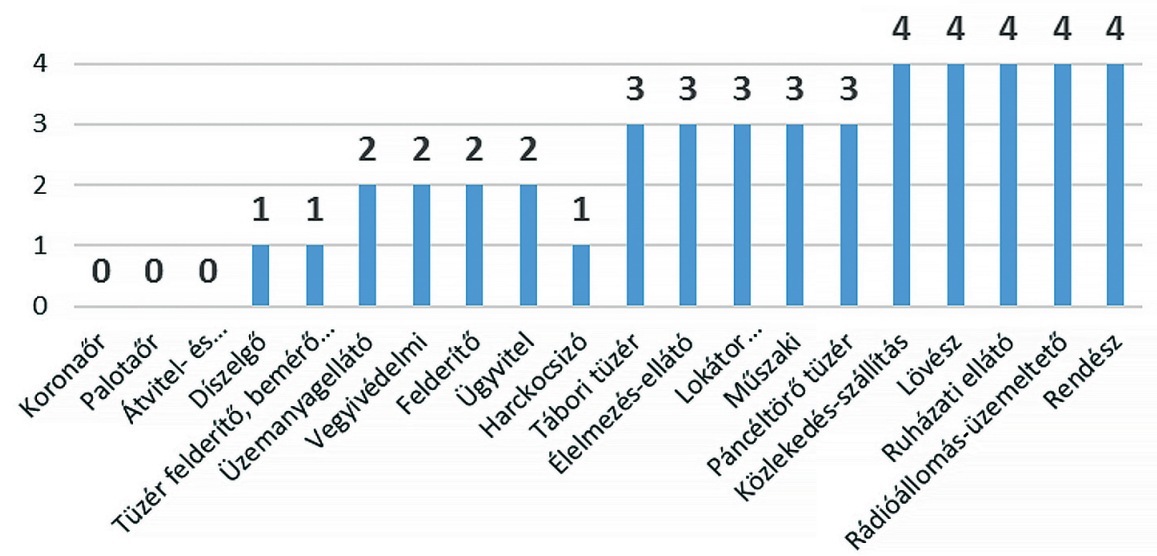

12. ábra: A végrehajtott altiszti szakmai tanfolyamok száma a vizsgált időszakban (2017-2019).

Forrás: a szerző szerkesztése 


\subsubsection{A vizsgált időszak képzéseinek fajlagos összehasonlitása (13. ábra)}

Érdemes megvizsgálni az egy tanfolyamra jutó fajlagos képzési létszámot. Így elemezve jól látható, hogy melyek azok a tanfolyamok, amelyek a vizsgált időszakban az egy kimenetre jutó fajlagos létszám tekintetében az 5 fő/tanfolyam létszámot sem érték el.

A 13. ábra az „Átlag tanfolyam adata” alatt mutatja az időszakban tervezett 46 képzés 10 fös átlaglétszámát, érzékeltetve, hogy melyek azok a képzések, amelyek az átlaglétszámhoz viszonyítva a létszám felett vagy alatt helyezkednek el.

Az 5 fö/tanfolyam létszámot el nem érő tanfolyamok esetében minden esetben felmerül a hatékony képzésszervezés felelőssége. Ez a szervezés nemcsak a tanfolyami képzésekre, hanem az MH AA-n folyó egyéb, államilag elismert képzésekre is negativ hatással volt. Az alultervezett csoportlétszámok felelőssége egyaránt terheli a beiskolázásban részt vevő és képzést kiíró szervezeteket. Különösen érdekes a csoportlétszám akkor, ha a képzési létszám a tanfolyamhoz tartozó oktatott eszköz kezelői létszámát sem adja ki. Az alultervezett képzési létszám túl drágává teszi a képzést, hiszen a beiskolázott 3-5 fő tanulóért a képzés teljes anyagi biztosítását meg kell valósítani, ezért elkerülhetetlen lenne egy minimum tanfolyami létszám központi meghatározása, amely alatt képzés nem lenne indítható.

Az adatokból az is látható, hogy mely területeken történt hatékony képzéstervezés. Kimagasló a Lövész és Közlekedés-szállítás képzések szervezése, hiszen 4 szervezett tanfolyam mellett is az átlagcsoportlétszámok 20 fö felett voltak.

Ettől jelentősen elmarad az Üzemanyag-ellátó, a Tüzér, felderítő, bemérő és a Harckocsizó képzési forma, amelyek esetében egy-két indított tanfolyam mellett, 2-3 fö a tanfolyami átlaglétszám.

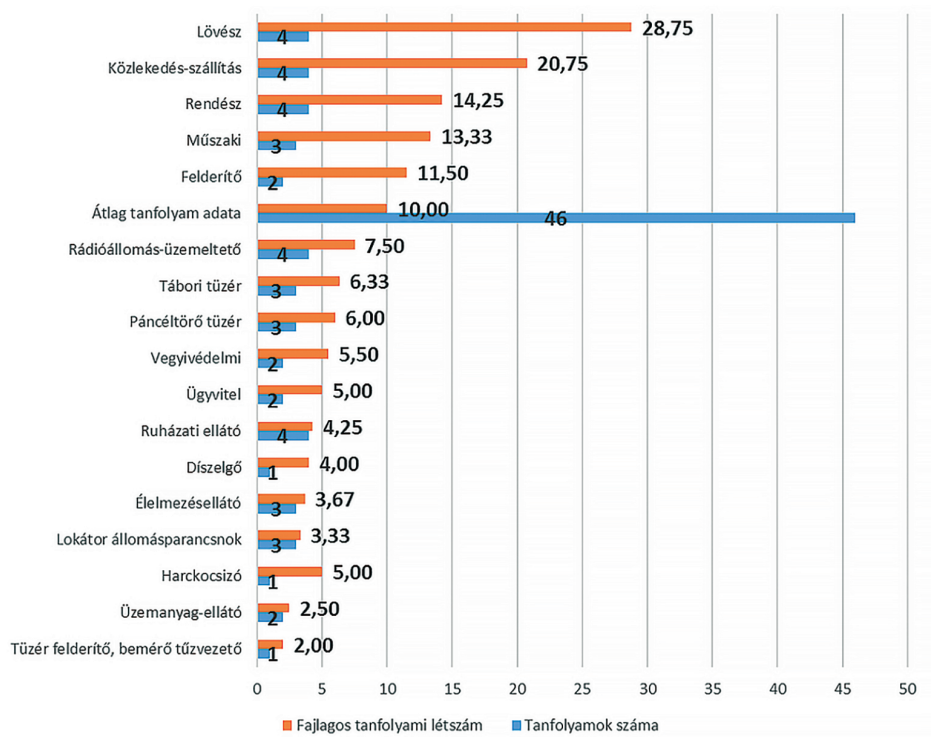

13. ábra: A fajlagos tanfolyami létszám a vizsgált időszakban (2017-2019).

Forrás: a szerző szerkesztése 
A Koronaőr, Palotaőr és a Híradó altiszti szaktanfolyam Átvitel- és kapcsolástechnikai eszközüzemeltető szakirányon - annak ellenére, hogy a képzési programok rendelkezésre álltak, és a lehetőség megvolt a képzések indításához - a két év alatt képzést nem indítottak.

\section{5. Összegzés}

A cikk a rövidített idejü, belső képzési rendszerü, tanfolyami keretek között folyó, a szerződéses legénységi állomány bázisára épülő altisztképzés 2017. szeptembertől 2019. júliusig terjedő időszakát mutatta be a kezdetektől a képzési forma befejezéséig. A képzést 2019 augusztusától az „Acélkocka” altisztképzési rendszer váltotta fel.

Az elemzés alapján az egyes tanfolyamok alacsony fajlagos tanfolyami létszáma alapján, a rövidített idejü altisztképzésben érzékelhető probléma az MH AA oktatói kapacitásának nem túl hatékony kihasználása. A két-három alkalommal indított képzések mellett megjelenő 5 fő vagy ez alatti átlag képzési létszámok minden esetben más képzési formáktól vonnak el oktatókat. A probléma hatékonyabb beiskolázástervezéssel feloldható lenne, de ehhez összehangolt szervezés szükséges, ahol az 5 fö alatti létszámmal képzéseket nem indítanának.

A képzési forma kétéves élettartama is elgondolkodtató, mert a gyors képzésváltás miatt nehezen vonható le az a következtetés, hogy az indítás során célul kitüzött szakmai és képzési kibocsátási eredményeket maradéktalanul beváltotta.

Fontos hangsúlyozni, hogy az elemzés csak az MH AA képzési rendszerének egy szeletét mutatta be. A hatékony müködés az MH AA képzési síkjainak egymásra hatását is figyelembe vevő tervezéssel valósitható meg. A cikk ennek vizsgálatára nem vállalkozott, de egy-egy jelenséget felszínre hozott. A kihelyezett képzéseket nemcsak a technikai feltételek hiánya miatt valósították meg az alakulatoknál, hanem azért, mert a legtöbb esetben a humán erőforrás is hiányzott a képzőintézménynél.

$\mathrm{Az}$ „Acélkocka” szakmai képzés előkészitési folyamatának egyik eredménye, hogy egyértelműen meghatározottá váltak az egyes fegyvernemekhez tartozó gyakorlati képzőhelyek, ahol a gyakorlati képzést meg lehet és meg kell valósítani. A szakmai felkészités szakmaiságának erősítése érdekében megfontolandó az MH AA állományában meglévő, többéves képzési tapasztalattal rendelkező jól felkészült, magasan kvalifikált oktatók képzésbe történő bevonása. Az elméleti képzés az MH AA bázisán hatékonyabban és olcsóbban megvalósítható lenne, hiszen a képzési és elhelyezési feltételek az elméleti oktatáshoz adottak. Az elméleti képzések központosított végrehajtását erősíti az egyes képzések összfegyvernemi jellege, struktúrája, amelynek hatékony oktatása az aktuális területen felkészült oktatók munkájának harmonikus összehangolása révén valósulhat meg. Az egyes képzőközpontokban megvalósítható, egy-egy oktatóra és szakoktatóra épített elaprózott képzési szerkezet hasonló hatékonyságra nem, vagy csak nehezen lehet képes. 


\section{Internetes forrás}

Intézménykereső. Oktatási Hivatal. Elérhető: www.oktatas.hu/hivatali_ugyek/kir_ intezmenykereso/!KIR_Intezmenykereso/Intezmeny/Index/100526 (A letöltés dátuma: 2020. 02. 12.)

\section{Jogi források}

309/2017. (HK 9.) HVKF intézkedés a Magyar Honvédség belső altisztképzési rendszerének átalakításáról és szabályozásáról

279/2018. (HK 9.) HVKF intézkedés a Magyar Honvédség belső altisztképzési rendszerének átalakításáról és szabályozásáról

248/2019. (HK 7.) MH PK intézkedés a Magyar Honvédség belső altisztképzési rendszeréröl

528/2011. (HK 12.) HVKF intézkedés a Magyar Honvédség belső tiszthelyettes képzési rendszerének bevezetéséröl 